\title{
Application of FDG-PET/CT in radiation oncology
}

\section{Jun $\mathrm{Li}^{*}$ and Ying Xiao}

Department of Radiation Oncology, Thomas Jefferson University, Philadelphia, PA, USA

\section{Edited by:}

Ilja F. Ciernik, Städtisches Klinikum

Dessau, Germany

Reviewed by:

Jesper Thygesen, Region Midtjylland, Denmark

Mustafa E. Altinyay, National Guard

Health Affairs, Saudi Arabia

*Correspondence:

Jun Li, Department of Radiation

Oncology, Thomas Jefferson

University, 111 South 11th Street,

Philadelphia, PA 19107, USA.

e-mail: jun.li@jefferson.edu
Positron emission tomography (PET)/computed tomography (CT), which combines the advantages of high sensitivity and specificity of PET and high resolution of $\mathrm{CT}$, is a unique tool for cancer management. PET/CT has been widely used in cancer diagnosis and treatment. The article reviews the recent applications of PET/CT in radiation oncology, with a focus on ${ }^{18} \mathrm{~F}$-fluorodeoxyglucose (FDG)-PET/CT, addressing the applications in treatment planning and treatment response assessment of radiation therapy.

Keywords: PET/CT, radiation oncology, radiation therapy, treatment response, treatment planning

\section{INTRODUCTION}

With high sensitivity and specificity, positron emission tomography (PET) is playing an important role in cancer imaging and treatment (Histed et al., 2012; Sveistrup et al., 2012). Combining with computed tomography (CT), PET can provide valuable information on tumor extent for most cancers (Ling et al., 2000). $\mathrm{PET} / \mathrm{CT}$ has been successfully used in the diagnosis, initial staging, and response assessment in various malignant tumors with high diagnostic accuracy (Borst et al., 2005; Eschmann et al., 2006; Facey et al., 2007) and has been used for PET-guided radiation treatment planning (Jarritt et al., 2006; Gregoire et al., 2007). ${ }^{18} \mathrm{~F}$ fluorodeoxyglucose (FDG) is the only Medicare approved PET/CT tracer for cancer imaging and FDG-PET/CT is the most widely available PET/CT procedure used in daily oncology practice. Studies have shown that FDG-PET/CT improves staging accuracy, with a $20-30 \%$ improvement in specificity and sensitivity over CT scanning (Toloza et al., 2003; Rodríguez Fernández et al., 2007; Yi et al., 2008). PET/CT systems offer a unique opportunity of improving target localization and facilitating treatment planning for radiation therapy. The advent of integrated or hybrid PET/CT scanners, which has facilitated hardware fusion of PET and CT data sets and improves the accuracy of target localization as compared to the procedures using software fusion of PET and CT scans acquired on separate scanners, have been used popularly nowadays. This study is to review the recent applications of PET/CT in radiation oncology, i.e., in radiation treatment response assessment and treatment planning, with a focus on FDG-PET/CT.

\section{PET/CT FOR RADIATION TREATMENT PLANNING}

Positron emission tomography/CT has been increasingly applied for target delineation in radiation treatment planning for a variety of cancer treatments, e.g., cervix, lung, head and neck (HN), and prostate, etc. (Erdi et al., 2002; Bradley et al., 2004; Lavrenkov et al., 2005; Nestle et al., 2005; Paulino et al., 2005; Greco et al., 2007; Lin et al., 2007; van Baardwijk et al., 2007; Dolezelova et al.,
2008; Henriques de Figueiredo et al., 2009; MacManus et al., 2009; Yu et al., 2009; De Jong et al., 2010; Terezakis et al., 2011; Lee et al., 2012).

Studies showed that FDG-PET/CT improved the accuracy of target definition (Nestle et al., 2006; MacManus et al., 2009) and PET/CT reduced the inter-observer variability compared to CT alone (Tejwani et al., 2012). PET/CT helps in finding CTundetected or borderline sized nodes and improves target accuracy for nodal radiation. For lung cancer, PET/CT showed high sensitivity and specificity for mediastinal lymph node involvement over CT. FDG-PET/CT can be used to differentiate tumor from collapsed lung and normal tissue, and defines disease extent in the chest wall. Studies had showed the differences of volumes contoured based on PET/CT and those contoured based on CT alone. For HN cancer, PET/CT can identify metastatic nodal disease which CT cannot. Studies have showed significant differences between PET/CT-derived and CT-derived tumor volumes in HN patients. Garg et al.'s (2012) study showed that PET/CT led to modification in treatment planning in 55\% of the $\mathrm{HN}$ patients studied. For cervical cancer, PET/CT has showed high sensitivity and specificity in initial staging and restaging cervical cancer and PET/CT has the advantage of detecting gross para-aortic and pelvic lymph nodes (PLNs) for treatment planning, which CT may not be able to detect. Incorporation of PET/CT into radiotherapy planning has the potential to allow radiation-dose escalation without increasing side effects (De Ruysscher et al., 2005; Pinkawa et al., 2012). Radiation treatment can be improved by using PET/CT for target volume delineation: doses to the tumor can be increased and organs at risk (OARs) can be spared. A summary of PET/CT applications in radiation treatment planning is provided in Table 1.

Positron emission tomography/CT images are used in two ways in radiation treatment planning: for PET/CT images acquired from a diagnostic scanner, the images are registered/fused with planning CT images; for PET/CT images acquired on a dedicated planning PET/CT scanner, the images are directly used 
Table 1 | Application of PET/CT in radiation treatment planning.

\begin{tabular}{|c|c|c|}
\hline Reference & Site of tumor & Results/Conclusion \\
\hline $\begin{array}{l}\text { Dolezelova et al. } \\
\text { (2008) }\end{array}$ & $\begin{array}{l}\text { Cervix (external } \\
\text { beam and HDR) }\end{array}$ & $\begin{array}{l}\text { PET/CT plays an important role in diagnosis and treatment of cervical carcinoma and in determination of } \\
\text { target volumes }\end{array}$ \\
\hline Lin et al. (2007) & $\begin{array}{l}\text { Cervix (LDR and } \\
\text { HDR) }\end{array}$ & $\begin{array}{l}\text { FDG-PET/CT-based treatment planning allowed for improved dose coverage of the tumor without } \\
\text { significantly increasing the dose to the bladder and rectum }\end{array}$ \\
\hline Tejwani et al. (2012) & Cervix & Inter-observer GTV variability decreased in PET/CT-based planning compared to CT-based planning \\
\hline Paulino et al. (2005) & Head and neck & PET/CT-based GTVs were different from CT-based GTVs in most cases \\
\hline $\begin{array}{l}\text { Henriques de } \\
\text { Figueiredo et al. } \\
\text { (2009) }\end{array}$ & Head and neck & Volume comparison showed a reduction and qualitative discrepancies between the PET- and CT-volumes \\
\hline Garg et al. (2012) & Head and neck & PET/CT led to a modification in treatment planning in $55 \%$ of patients studied \\
\hline $\begin{array}{l}\text { De Jong et al. } \\
\text { (2010) }\end{array}$ & Prostate & Review of PET/CT and radiotherapy in prostate cancer patients \\
\hline $\begin{array}{l}\text { Pinkawa et al. } \\
\text { (2012) }\end{array}$ & Prostate & $\begin{array}{l}\text { Treatment planning with (18)F-choline PET-CT allows a dose escalation to a macroscopic intraprostatic lesion } \\
\text { without significantly increasing toxicity }\end{array}$ \\
\hline $\begin{array}{l}\text { Terezakis et al. } \\
\text { (2011) }\end{array}$ & Lymphoma & $\begin{array}{l}\text { PET/CT-based treatment planning for lymphoma patients resulted in considerable changes in management, } \\
\text { volume definition, and normal tissue dosimetry }\end{array}$ \\
\hline $\begin{array}{l}\text { Yeoh and Mikhaeel } \\
\text { (2013) }\end{array}$ & Lymphoma & Critical review of incorporating PET/CT into radiation therapy of Iymphoma \\
\hline Erdi et al. (2002) & NSCLC & There was a change in PTV outline based on CT images versus CT/PET fused images \\
\hline $\begin{array}{l}\text { Bradley et al. } \\
(2004)\end{array}$ & NSCLC & $\begin{array}{l}\text { Biologic targeting with PET alters the radiation treatment volume significantly in 30-60\% of NSCLC } \\
\text { patients for whom definitive therapy is planned }\end{array}$ \\
\hline Greco et al. (2007) & NSCLC & $\begin{array}{l}\text { Significant impact of PET-derived contours on treatment planning was shown in } 30-60 \% \text { of the plans with } \\
\text { respect to the CT-only target volume }\end{array}$ \\
\hline $\begin{array}{l}\text { van Baardwijk et al. } \\
\text { (2007) }\end{array}$ & NSCLC & $\begin{array}{l}\text { Source-to-background ratio-based auto-delineation showed a good correlation with pathology, decreased } \\
\text { the delineated volumes of the GTVs, and reduced the inter-observer variability }\end{array}$ \\
\hline Nestle et al. (2005) & NSCLC & $\begin{array}{l}\text { Different techniques of tumor contour definition by (18)F-FDG-PET in radiotherapy planning lead to } \\
\text { substantially different volumes }\end{array}$ \\
\hline Yu et al. (2009) & NSCLC & Integrated 18F-FDG-PET/CT is an effective tool to define the target of GTV in radiotherapy \\
\hline $\begin{array}{l}\text { Lavrenkov et al. } \\
\text { (2005) }\end{array}$ & NSCLC & PET results in a reduction in the CT-derived GTV for NSCLC primary target volume in $15 \%$ of the patients \\
\hline $\begin{array}{l}\text { De Ruysscher et al. } \\
\text { (2005) }\end{array}$ & NSCLC & $\begin{array}{l}\text { The use of a combined dedicated } \mathrm{PET/CT} \text { allowed significant radiation-dose escalation whilst respecting all } \\
\text { relevant normal tissue constraints }\end{array}$ \\
\hline Nestle et al. (2006) & NSCLC & $\begin{array}{l}\text { Review of technical factors influencing PET and PET/CT data, and their consequences for radiotherapy } \\
\text { planning }\end{array}$ \\
\hline Lee et al. (2012) & Lung & Review of FDG-PET/CT-based radiation treatment planning for lung cancer \\
\hline
\end{tabular}

Treatments using brachytherapy are indicated.

for treatment planning. To register/fuse the diagnostic PET/CT images acquired in non-treatment position, with planning CT images acquired in treatment position, software for image registration/fusion are needed. Usually rigid image registration is performed. Rigid image registration accounts for only linear or uniform transformation within six degrees of freedom.
Recently, deformable registration which can account for significant temporal and anatomic changes between the image sets, has been applied for PET/CT-CT image fusion. The study of Kovalchuk et al. (2012) has demonstrated that deformable registration is a powerful tool for the image fusion of diagnostic PET/CT and planning CT for target volume delineation. 
Table 2 | Application of PET/CT in radiation treatment response.

\begin{tabular}{|c|c|c|}
\hline Reference & Site of tumor & Results/Conclusion \\
\hline $\begin{array}{l}\text { Bussink et al. } \\
\text { (2011) }\end{array}$ & Various & $\begin{array}{l}\text { (Review) Discussion of the potential of integrated PET-CT for treatment selection, response monitoring } \\
\text { early after the start of treatment, and prediction of outcome for solid tumors }\end{array}$ \\
\hline $\begin{array}{l}\text { Caldarella et al. } \\
\text { (2012) }\end{array}$ & Osteosarcoma & Review of FDG-PET/CT in assessing response to neoadjuvant treatment in patients with osteosarcoma \\
\hline $\begin{array}{l}\text { Cheebsumon et al. } \\
\text { (2012) }\end{array}$ & NSCLC & PET-based tumor delineation methods provided tumor sizes in agreement with pathology \\
\hline Choi et al. (2002) & NSCLC & $\begin{array}{l}\text { Correlation between the gradient of residual metabolic rate of glucose after chemoradiotherapy and the } \\
\text { probability of tumor control on the basis of pathologic tumor response is an inverse dose-response } \\
\text { relationship }\end{array}$ \\
\hline $\begin{array}{l}\text { Grigsby et al. } \\
\text { (2004) }\end{array}$ & Cervix & $\begin{array}{l}\text { Post-therapy abnormal FDG uptake (persistent or new) as detected by whole-body PET measures tumor } \\
\text { response and might be predictive of tumor recurrence and death from cervical cancer }\end{array}$ \\
\hline Hicks et al. (2004) & NSCLC & $\begin{array}{l}\text { Post-radiotherapy inflammatory changes detected by FDG-PET are positively correlated with tumor } \\
\text { response }\end{array}$ \\
\hline Hicks (2005) & Various & (Review) The potential benefits and limitations of FDG-PET were discussed \\
\hline Huh et al. (2012) & Rectum & $\begin{array}{l}\text { The FDG-PET/CT parameters and the response index may be best for assessing the neoadjuvant } \\
\text { chemoradiation response of locally advanced rectal cancer }\end{array}$ \\
\hline $\begin{array}{l}\text { Janssen et al. } \\
\text { (2012) }\end{array}$ & Rectum & $\begin{array}{l}\text { The presented predictive model could be used to select patients to be considered for less invasive surgical } \\
\text { interventions or even a "wait and see" policy }\end{array}$ \\
\hline Jeong et al. (2002) & NSCLC & (18)F-FDG uptake correlated with survival in NSCLC \\
\hline $\begin{array}{l}\text { Juweid and } \\
\text { Cheson (2006) }\end{array}$ & Various & $\begin{array}{l}\text { (Review) The use of 18F-FDG-PET in the assessment of cancer after therapy, including restaging tumors } \\
\text { and monitoring tumor response, was discussed }\end{array}$ \\
\hline Kalff et al. (2006) & Rectum & $\begin{array}{l}\text { Post-chemoradiation (18)F-FDG-PET scintigraphy provides good medium-term prognostic information in } \\
\text { patients with advanced rectal cancer undergoing radical surgery with curative intent }\end{array}$ \\
\hline Kidd et al. (2010) & Cervix & $\begin{array}{l}\text { SUV is a prognostic biomarker, predicting treatment response, pelvic recurrence risk, and disease-specific } \\
\text { survival }\end{array}$ \\
\hline Lee et al. (2013) & Cervix & $\begin{array}{l}\text { Significant decreases in tumor volume were observed on PET/CT images during and after concurrent } \\
\text { chemoradiotherapy }\end{array}$ \\
\hline Perez et al. (2012) & Rectum & $\begin{array}{l}\text { Assessment of tumor response at } 12 \text { weeks after chemoradiation completion with PET/CT imaging may } \\
\text { provide a useful additional tool with good overall accuracy for the selection of patients }\end{array}$ \\
\hline Petit et al. (2009) & NSCLC & A methodology was presented to derive relationships between FDG uptake, dose, and metabolic control \\
\hline $\begin{array}{l}\text { Porceddu et al. } \\
\text { (2011) }\end{array}$ & Head and neck & $\begin{array}{l}\text { PET-directed management of the neck after definitive RT in node-positive HNSCC appropriately spares neck } \\
\text { dissections in patients with PET-negative residual CT nodal abnormalities }\end{array}$ \\
\hline $\begin{array}{l}\text { Pöttgen et al. } \\
\text { (2006) }\end{array}$ & NSCLC & $\begin{array}{l}\text { SUV values from two serial PET/CT scans, before and after three chemotherapy cycles or later, allow } \\
\text { prediction of histopathologic response in the primary tumor and mediastinal lymph nodes and have } \\
\text { prognostic value }\end{array}$ \\
\hline Rege et al. (2000) & Head and neck & $\begin{array}{l}\text { Pretreatment PET findings may have prognostic implications in determining which patients will achieve } \\
\text { long-term local control with primary radiation therapy }\end{array}$ \\
\hline Vaidya et al. (2012) & NSCLC & $\begin{array}{l}\text { Multimodality image-feature modeling provides better performance compared to existing metrics and holds } \\
\text { promise for individualizing radiotherapy planning }\end{array}$ \\
\hline $\begin{array}{l}\text { van Loon et al. } \\
\text { (2011) }\end{array}$ & SCLC & $\begin{array}{l}\text { Both early CT and FDG-metabolic tumor volume changes show a significant correlation with survival in } \\
\text { SCLC }\end{array}$ \\
\hline $\begin{array}{l}\text { van Stiphout et al. } \\
\text { (2011) }\end{array}$ & Rectum & $\begin{array}{l}\text { The model and the nomogram developed based on clinical and sequential PET-CT data can accurately } \\
\text { predict pathologic complete response }\end{array}$ \\
\hline
\end{tabular}


The use of dedicated PET/CT systems for treatment planning is increasing in radiation oncology. The advantage is that the system produces co-registered images with the patient in the treatment position and the images can be used directly for treatment planning without image fusion with another planning CT. Thus the accuracy of target volume delineation is improved.

For target volume delineation on PET/CT images, manual or automated method is used. It is challenging to identify lesion edges in noisy PET data. The manual delineation relies on clinician's expertise and is also limited by image display settings, e.g., window level and width. The automated delineation is based on quantitative or semi-quantitative techniques derived from the standardized uptake value (SUV), which assesses the level of FDG uptake. The basic idea is to decide a cutoff of measured SUV to separate target from background tissues. Various techniques of automated delineation have been studied (Lee, 2010). There are concerns of the accuracy of automated delineation. Yeoh and Mikhaeel's (2013) paper emphasized that one must be cautious when adopting automated volume delineation using PET/CT information because there can be significant variation depending on the parameters and segmentation techniques used.

A limiting factor for accurate target volume delineation by $\mathrm{PET} / \mathrm{CT}$ is organ and tumor motion caused by patient respiration. Respiration introduces artifacts in CT and PET images, which can result in degraded image quality and can lead to possible tumor missing from treatment volumes or under-treatment. Methods have been developed for motion management in PET/CT for radiation treatment planning, which include 4D PET/CT and deep inspiration breath-holding PET/CT (Nehmeh et al., 2004, 2007; Bettinardi et al., 2012; Scripes and Yaparpalvi, 2012).

\section{PET/CT FOR TREATMENT RESPONSE ASSESSMENT}

${ }^{18} \mathrm{~F}$-fluorodeoxyglucose-PET/CT has been frequently used to monitor the response of cancer treatment (Rege et al., 2000; Choi et al., 2002; Jeong et al., 2002; Hicks et al., 2004; Hicks, 2005; Gagel et al., 2006; Juweid and Cheson, 2006; Pöttgen et al., 2006; Bussink et al., 2011; Porceddu et al., 2011; Caldarella et al., 2012; Cheebsumon et al., 2012; Huh et al., 2012; Janssen et al., 2012; Perez et al., 2012; Vaidya et al., 2012; Lee et al., 2013). Studies have demonstrated the potential of using FDG to predict response and survival in different cancer sites (Grigsby et al., 2004; Hicks et al., 2004; Kalff et al., 2006; Petit et al., 2009; van Loon et al., 2011; van Stiphout et al., 2011). Kidd et al. (2010) evaluated the prognostic significance of the maximum SUV( $\max$ ) of FDG in a study of 83 cervical cancer patients. In the study, the SUV(PLN) was analyzed for its association with treatment response, pelvic disease recurrence, disease-specific survival, and overall survival. The SUV(PLN) was found to be correlated with an increased risk of persistent disease after treatment $(P=0.0025)$, specifically within the PLN region $(P=0.0003)$, and was found to be

\section{REFERENCES}

Bettinardi, V., Picchio, M., Di Muzio, N., and Gilardi, M. C. (2012). Motion management in positron emission tomography/computed tomography for radiation treatment planning. Semin. Nucl. Med. 42, 289-307.
Borst, G. R., Belderbos, J. S., Boellaard, R., Comans, E. F., De Jaeger, K., Lammertsma, A. A., et al. (2005). Standardised FDG uptake: a prognostic factor for inoperable non-small cell lung cancer. Eur. J. Cancer 41, 1533-1541.

predictive of an increased risk of ever developing pelvic disease recurrence $(P=0.0035)$. Patients with a higher SUV $(P L N)$ were found to have significantly worse disease-specific $(P=0.0230)$ and overall survival $(P=0.0378)$. The study showed that SUV(PLN) is a prognostic biomarker, which can predict treatment response, pelvic recurrence risk, and disease-specific survival in patients with cervical cancer. A summary of PET/CT applications in radiation treatment response is provided in Table 2 .

A study has demonstrated that a high SUV for FDG in the primary tumor and regional nodes after completion of radiotherapy predicted poor treatment response and tumor control in nonsmall cell lung cancer (Jeong et al., 2002). Rege et al.'s (2000) study in $\mathrm{HN}$ patients showed that PET findings might have prognostic implications in determining which patients will achieve long-term local control with primary radiation therapy and might help identify those patients at increased risk of recurrence that may benefit from more aggressive altered fractionation schemes or combined modality therapy. Jeong et al.'s (2002) study showed that the detection of residual and recurrent disease by FDG-PET/CT has a reported sensitivity of $100 \%$, specificity of $92 \%$, positive predictive value of $92 \%$, negative predictive value of $100 \%$, and diagnostic accuracy of $96 \%$.

A recent study enrolling 50 patients with locally advanced rectal cancer assessed the value of sequential FDG-PET/CT scans for predicting the response of locally advanced rectal cancer to neoadjuvant chemoradiation (Huh et al., 2012). The treatment consisted of concurrent chemoradiation, which included preoperative 5-fluorouracil-based chemotherapy and pelvic radiation (4500 to $5040 \mathrm{cGy}$ ). All the patients underwent FDG-PET/CT before and 5 weeks later (median: $35 \mathrm{~d}$ ) after the completion of chemoradiation. After chemoradiation, 32 of 50 patients $(64 \%)$ were classified as responders according to the tumor regression grade. For all the patients, the mean pre-chemoradiation $\mathrm{SUV}(\max )$ was significantly higher than the mean SUV(max) value at post-chemoradiation $(P<0.001)$. The mean response index was significantly higher in the responders than that in the non-responder patients $(P=0.001)$. The study concluded that the FDG-PET/CT parameters and especially the mean response index, may be best for assessing the neoadjuvant chemoradiation response of locally advanced rectal cancer and those values can potentially assist physicians for planning the optimal treatment.

\section{CONCLUSION}

Positron emission tomography/CT is being actively used in radiation oncology for treatment response assessment and treatment planning. Careful attention needs to be paid to the details in applications, e.g., image fusion, automated image segmentation, and patient motion management. PET/CT, a valuable tool for radiation oncology, is bringing significant impact on radiation treatment.

Bradley, J. D., Perez, C. A., Dehdashti, F., and Siegel, B. A. (2004). Implementing biologic target volumes in radiation treatment planning for non-small cell lung cancer. J. Nucl. Med. 45(Suppl. 1), 96S-101S.
Bussink, J., Kaanders, J. H., van der Graaf, W. T., and Oyen, W. J. (2011). PET-CT for radiotherapy treatment planning and response monitoring in solid tumors. Nat. Rev. Clin. Oncol. 8, 233-242. 
Caldarella, C., Salsano, M., Isgrò, M. A., and Treglia, G. (2012). The role of fluorine-18-fluorodeoxyglucose positron emission tomography in assessing the response to neoadjuvant treatment in patients with osteosarcoma. Int. J. Mol. Imaging 2012, 870301.

Cheebsumon, P., Boellaard, R., de Ruysscher, D., van Elmpt, W., van Baardwijk, A., Yaqub, M., et al. (2012). Assessment of tumour size in PET/CT lung cancer studies: PETand CT-based methods compared to pathology. EJNMMI Res. 2, 56.

Choi, N. C., Fischman, A. J., Niemierko, A., Ryu, J. S., Lynch, T., Wain, J., et al. (2002). Dose-response relationship between probability of pathologic tumor control and glucose metabolic rate measured with FDG PET after preoperative chemoradiotherapy in locally advanced non-small cell lung cancer. Int. J. Radiat. Oncol. Biol. Phys. 54, 1024-1035.

De Jong, I. J., De Haan, T. D., Wiegman, E. M., Van Den Bergh, A. C., Pruim, J., and Breeuwsma, A. J. (2010). PET/CT and radiotherapy in prostate cancer. Q. J. Nucl. Med. Mol. Imaging 54, 543-552.

De Ruysscher, D., Wanders, S., Minken, A., Lumens, A., Schiffelers, J., Stultiens, C., et al. (2005). Effects of radiotherapy planning with a dedicated combined PET-CT-simulator of patients with non-small cell lung cancer on dose limiting normal tissues and radiation dose-escalation: a planning study. Radiother. Oncol.77, 5-10.

Dolezelova, H., Slampa, P., Ondrova, B., Gombosova, J., Sovadinova, S., Novotny, T., et al. (2008). The impact of PET with 18FDG in radiotherapy treatment planning and in the prediction in patients with cervix carcinoma. Results of pilot study. Neoplasma 55, 437-441.

Erdi, Y. E., Rosenzweig, K., Erdi, A. K., MacApinlac, H. A., Hu, Y. C., Braban, L. E., et al. (2002). Radiotherapy treatment planning for patients with non-small cell lung cancer using positron emission tomography (PET). Radiother. Oncol. 62, 51-60.

Eschmann, S. M., Friedel, G., Paulsen, F., Reimold, M., Hehr, T., Budach, W., et al. (2006). Is standardised (18)F-FDG uptake value an outcome predictor in patients with stage III non-small cell lung cancer? Eur. J. Nucl. Med. Mol. Imaging 33, 263-269.

Facey, K., Bradbury, I., Laking, G., and Payne, E. (2007). Overview of the clinical effectiveness of positron emission tomography in selected cancers. Health Technol. Assess. 11, 3-4.

Gagel, B., Reinartz, P., Demirel, C., Kaiser, H. J., Zimny, M., Piroth, M., et al. (2006). [18F] Fluoromisonidazole and $[18 \mathrm{~F}]$ fluorodeoxyglucose positron emission tomography in response evaluation after chemo/radiotherapy of non-small-cell lung cancer: a feasibility study. $B M C$ Cancer 6:51. doi:10.1186/14712407-6-51

Garg, M. K., Glanzman, J., and Kalnicki, S. (2012). The evolving role of positron emission tomographycomputed tomography in organpreserving treatment of head and neck cancer. Semin. Nucl. Med. 42, 320-327.

Greco, C., Rosenzweig, K., Cascini, G. L., and Tamburrini, O. (2007). Current status of PET/CT for tumour volume definition in radiotherapy treatment planning for non-small cell lung cancer (NSCLC). Lung Cancer 57, 125-134.

Gregoire, V., Haustermans, K., Geets, X., Roels, S., and Lonneux, M. (2007). PET-based treatment planning in radiotherapy: a new standard? J. Nucl. Med. 48, 68S-77S.

Grigsby, P. W., Siegel, B. A., Dehdashti, F., Rader, J., and Zoberi, I. (2004). Post-therapy [18F] fluorodeoxyglucose positron emission tomography in carcinoma of the cervix: response and outcome. J. Clin. Oncol. 22, 2167-2171.

Henriques de Figueiredo, B., Barret, O., Demeaux, H., Lagarde, P., DeMones-Del-Pujol, E., Kantor, G., et al. (2009). Comparison between CTand FDG-PET defined target volumes for radiotherapy planning in head and neck cancers. Radiother. Oncol. 93, 479-482.

Hicks, R. J. (2005). The role of PET in monitoring therapy. Cancer Imaging 5, 51-57.

Hicks, R. J., Mac Manus, M. P., Matthews, J. P., Hogg, A., Binns, D., Rischin, D., et al. (2004). Early FDGPET imaging after radical radiotherapy for non-small-cell lung cancer: inflammatory changes in normal tissues correlate with tumor response and do not confound therapeutic response evaluation. Int. J. Radiat. Oncol. Biol. Phys. 60, 412-418.

Histed, S. N., Lindenberg, M. L., Mena, E., Turkbey, B., Choyke, P. L., and Kurdziel, K. A. (2012). Review of functional/anatomical imaging in oncology. Nucl. Med. Commun. 33, 349-361.
Huh, J. W., Min, J. J., Lee, J. H., Kim, H. R., and Kim, Y. J. (2012). The predictive role of sequential FDG-PET/CT in response of locally advanced rectal cancer to neoadjuvant chemoradiation. Am. J. Clin. Oncol. 35, 340-344.

Janssen, M. H., Öllers, M. C., van Stiphout, R. G., Riedl, R. G., van den Bogaard, J., Buijsen, J., et al. (2012). PET-based treatment response evaluation in rectal cancer: prediction and validation. Int. J. Radiat. Oncol. Biol. Phys. 82, 871-876.

Jarritt, P. H., Carson, K. J., Hounsell, A. R., and Visvikis, D. (2006). The role of PET/CT scanning in radiotherapy planning. Br. J. Radiol. 79, S27-S35.

Jeong, H. J., Min, J. J., Park, J. M. Chung, J. K., Kim, B. T., Jeong, J. M., et al. (2002). Determination of the prognostic value of [(18)F]fluorodeoxyglucose uptake by using positron emission tomography in patients with non-small cell lung cancer. Nucl. Med. Commun. $23,865-870$.

Juweid, M. E., and Cheson, B. D. (2006). Positron-emission tomography and assessment of cancer therapy. $N$. Engl. J. Med. 354, 496-507.

Kalff, V., Duong, C., Drummond, E. G., Hicks, J. P., and Matthews, R. J. (2006). Findings on 18F-FDG PET scans after neoadjuvant chemoradiation provides prognostic stratification in patients with locally advanced rectal carcinoma subsequently treated by radical surgery. $J$. Nucl. Med. 47, 14-22.

Kidd, E. A., Siegel, B. A., Dehdashti, F., and Grigsby, P. W. (2010). Pelvic lymph node F-18 fluorodeoxyglucose uptake as a prognostic biomarker in newly diagnosed patients with locally advanced cervical cancer. Cancer 116, 1469-1475.

Kovalchuk, N., Jalisi, S., Subramaniam, R. M., and Truong, M. T. (2012). Deformable registration of preoperative PET/CT with postoperative radiation therapy planning $\mathrm{CT}$ in head and neck cancer. Radiographics 32, 1329-1341.

Lavrenkov, K., Partridge, M., Cook, G., and Brada, M. (2005). Positron emission tomography for target volume definition in the treatment of non-small cell lung cancer. Radiother. Oncol. 77, 1-4.

Lee, J. A. (2010). Segmentation of positron emission tomography images: some recommendations for target delineation in radiation oncology. Radiother. Oncol. 96, 302-307.

Lee, J. E., Huh, S. J., Nam, H., and Ju, S. G. (2013). Early response of patients undergoing concurrent chemoradiotherapy for cervical cancer: a comparison of PET/CT and MRI. Ann. Nucl. Med. 27, 37-45.

Lee, P., Kupelian, P., Czernin, J., and Ghosh, P. (2012). Current concepts in F18 FDG PET/CTbased radiation therapy planning for lung cancer. Front. Oncol. 2:71. doi:10.3389/fonc.2012.00071

Lin, L. L., Mutic, S., Low, D. A., LaForest, R., Vicic, M., Zoberi, I., et al. (2007). Adaptive brachytherapy treatment planning for cervical cancer using FDG-PET. Int. J. Radiat. Oncol. Biol. Phys. 67, 91-96.

Ling, C. C., Humm, J., Larson, S., Amols, H., Fuks, Z., Leibel, S., et al. (2000). Towards multidimensional radiotherapy (MD-CRT): biological imaging and biological conformality. Int. J. Radiat. Oncol. Biol. Phys. 47, 551-560.

MacManus, M., Nestle, U., Rosenzweig, K. E., Carrio, I., Messa, C., Belohlavek, O., et al. (2009). Use of PET and PET/CT for radiation therapy planning: IAEA expert report 2006-2007. Radiother. Oncol. 91, 85-94.

Nehmeh, S. A., Erdi, Y. E., Meirelles, G. S., Squire, O., Larson, S. M. and Schöder, H. (2007). Deepinspiration breath-hold PET/CT of the thorax. J. Nucl. Med. 48, 22-26.

Nehmeh, S. A., Erdi, Y. E., Pan, T., Pevsner, A., Rosenzweig, K. E., Yorke, E., et al. (2004). Four-dimensional (4D) PET/CT imaging of the thorax. Med. Phys. 31, 3179-3186.

Nestle, U., Kremp, S., and Grosu, A. L. (2006). Practical integration of [18F]-FDG-PET and PET$\mathrm{CT}$ in the planning of radiotherapy for non-small cell lung cancer (NSCLC): the technical basis, ICRU-target volumes, problems, perspectives. Radiother. Oncol. 81, 209-225.

Nestle, U., Kremp, S., Schaefer-Schuler, A., Sebastian-Welsch, C., Hellwig, D., Rube, C., et al. (2005). Comparison of different methods for delineation of 18F-FDG PET-positive tissue for target volume definition in radiotherapy of patients with non-small cell lung cancer. J. Nucl. Med. 46, 1342-1348.

Paulino, A. C., Koshy, M., Howell, R., Schuster, D., and Davis, L. W. (2005). Comparison of CT- and FDGPET-defined gross tumor volume in intensity-modulated radiotherapy for head-and-neck cancer. Int. J. Radiat. Oncol. Biol. Phys. 61, 1385-1392.

Perez, R. O., Habr-Gama, A., GamaRodrigues, J., Proscurshim, I., Julião, 
G. P., Lynn, P., et al. (2012). Accuracy of positron emission tomography/computed tomography and clinical assessment in the detection of complete rectal tumor regression after neoadjuvant chemoradiation: long-term results of a prospective trial (National Clinical Trial 00254683). Cancer 118, 3501-3511.

Petit, S. F., Aerts, H. J., van Loon, J. G., Offermann, C., Houben, R., Winkens, B., et al. (2009). Metabolic control probability in tumour subvolumes or how to guide tumour dose redistribution in nonsmall cell lung cancer (NSCLC): an exploratory clinical study. Radiother. Oncol. 91, 393-398.

Pinkawa, M., Piroth, M. D., Holy, R., Klotz, J., Djukic, V., Corral, N. E., et al. (2012). Dose-escalation using intensity-modulated radiotherapy for prostate cancer - evaluation of quality of life with and without (18)F-choline PET-CT detected simultaneous integrated boost. Radiat. Oncol. 7, 14.

Porceddu, S. V., Pryor, D. I., Burmeister, E., Burmeister, B. H., Poulsen, M. G., Foote, M. C., et al. (2011). Results of a prospective study of positron emission tomographydirected management of residual nodal abnormalities in nodepositive head and neck cancer after definitive radiotherapy with or without systemic therapy. Head Neck 33, 1675-1682.

Pöttgen, C., Levegrün, S., Theegarten, D., Marnitz, S., Grehl, S., Pink, R., et al. (2006). Value of 18F-fluoro-2deoxy-D-glucose-positron emission tomography/computed tomography in non-small-cell lung cancer for prediction of pathologic response and times to relapse after neoadjuvant chemoradiotherapy. Clin. Cancer Res. 12, 97-106.

Rege, S., Safa, A. A., Chaiken, L., Hoh, C., Juillard, G., and Withers, H. R. (2000). Positron emission tomography: an independent indicator of radiocurability in head and neck carcinomas. Am. J. Clin. Oncol. 23, 164-169.

Rodríguez Fernández, A., Gómez Río, M., Llamas Elvira, J. M., SánchezPalencia Ramos, A., Bellón Guardia, M., Ramos Font, C., et al. (2007). Diagnosis efficacy of structural (CT) and functional (FDG-PET) imaging methods in the thoracic and extrathoracic staging of non-small cell lung cancer. Clin. Transl. Oncol. 9, 32-39.

Scripes, P. G., and Yaparpalvi, R. (2012). Technical aspects of positron emission tomography/computed tomography in radiotherapy treatment planning. Semin. Nucl. Med. 42, 283-288.

Sveistrup, J., Loft, A., Berthelsen, A. K., Henriksen, B. M., Nielsen, M. B., and Engelholm, S. A. (2012). Positron emission tomography/computed tomography in the staging and treatment of anal cancer. Int. J. Radiat. Oncol. Biol. Phys. 83, 134-141.

Tejwani, A., Lavaf, A., Parikh, K., Mokhtar, B., Swamy, U., Emmolo, J., et al. (2012). The role of PET/CT in decreasing inter-observer variability in treatment planning and evaluation of response for cervical cancer. Am. J. Nucl. Med. Mol. Imaging 2, 307-313.

Terezakis, S. A., Hunt, M. A., Kowalski, A., McCann, P., Schmidtlein, C. R., Reiner, A., et al. (2011). [18F]FDGPositron emission tomography coregistration with computed tomography scans for radiation treatment planning of lymphoma and hematological malignancies. Int. J. Radiat. Oncol. Biol. Phys. 81, 615-622.

Toloza, E. M., Harpole, L., and McCrory, D. C. (2003). Noninvasive staging of non-small cell lung cancer: a review of the current evidence. Chest 123(Suppl. 1), 137S-146S.

Vaidya, M., Creach, K. M., Frye, J. Dehdashti, F., Bradley, J. D., and El Naqa, I. (2012). Combined PET/CT image characteristics for radiotherapy tumor response in lung cancer. Radiother. Oncol. 102, 239-245.

van Baardwijk, A., Bosmans, G. Boersma, L., Buijsen, J., Wanders, S., Hochstenbag, M., et al. (2007). PETCT-based auto-contouring in nonsmall-cell lung cancer correlates with pathology and reduces interobserver variability in the delineation of the primary tumor and involved nodal volumes. Int. J. Radiat. Oncol. Biol. Phys. 68, 771-778.

van Loon, J., Offermann, C., Ollers, M. van Elmpt, W., Vegt, E., Rahmy, A., et al. (2011). Early CT and FDGmetabolic tumour volume changes show a significant correlation with survival in stage I-III small cell lung cancer: a hypothesis generating study. Radiother. Oncol. 99, 72-75.

van Stiphout, R. G., Lammering, G. Buijsen, J., Janssen, M. H., Gambacorta, M. A., Slagmolen, P., et al. (2011). Development and external validation of a predictive model for pathological complete response of rectal cancer patients including sequential PET-CT imaging. Radiother. Oncol. 98, 126-133.

Yeoh, K. W., and Mikhaeel, N. G. (2013). Are we ready for positron emission tomography/computed tomography-based target volume definition in lymphoma radiation therapy. Int. J. Radiat. Oncol. Biol. Phys. 85, 14-20.

Yi, C. A., Shin, K. M., Lee, K. S., Kim, B. T., Kim, H., Kwon, O. J., et al. (2008). Non-small cell lung cancer staging: efficacy comparison of integrated PET/CT versus 3.0-T wholebody MR imaging. Radiology 248, 632-642.

Yu, H. M., Liu, Y. F., Hou, M., Liu, J., Li, X. N., and Yu, J. M. (2009). Evaluation of gross tumor size using CT, 18F-FDG PET, integrated 18F-FDG $\mathrm{PET} / \mathrm{CT}$ and pathological analysis in non-small cell lung cancer. Eur. J. Radiol. 72, 104-113.

Conflict of Interest Statement: The authors declare that the research was conducted in the absence of any commercial or financial relationships that could be construed as a potential conflict of interest.

Received: 14 December 2012; accepted: 28 March 2013; published online: 11 April 2013.

Citation: $\mathrm{Li} J$ and Xiao Y (2013) Application of FDG-PET/CT in radiation oncology. Front. Oncol. 3:80. doi: 10.3389/fonc.2013.00080

This article was submitted to Frontiers in Cancer Imaging and Diagnosis, a specialty of Frontiers in Oncology. Copyright $(5) 2013$ Li and Xiao. This is an open-access article distributed under the terms of the Creative Commons Attribution License, which permits use, distribution and reproduction in other forums, provided the original authors and source are credited and subject to any copyright notices concerning any third-party graphics etc. 